\title{
Covenant Markiage, and the Conflict of Laws
}

\section{LILY $\mathrm{NG}^{*}$}

Recently: three American states introduced covenam marriage as a new form of marriage in response' w the rising divorce rate. The anthor exomines the thres distinguishing characteristics of coicmam morriage that distinguish if from the corren form of morriage offered in the Unised States ame Camadk. For the Unitod States, the anthor camasices the possibility of scparating jurisdiction from choice of low: separating subject matler jurisdiction from persond juris diction. and recognition of the parties 'intent, as threepossible alternatives that non-covenant marrioge sfates can utilize in order to respect the parties intentions and the covenant marriage state s legislative intent. For Canoda, the author camasses the possihility that while Canada could take jurisdiction on the "ordisurily. residem" basis, they man refuse jurisdiction on the basis of forum non conveniens or, alternatively, that they may apply the substantive lan of the covernm marriage state on the basis that the Declaration of Iment signed by the parties represents an express choice of law clouse.
Tout dernierement, trois États américuins unt introdwit le mariage covenam comme une nomelle forme de

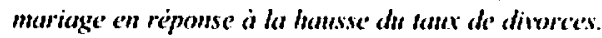
L'anteur examine les trois carneterisfigmes spicifiques de mariage colemam qui le distingure de la forme achelle de moriage propese and Fitats-Unis on an

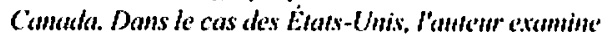
la possibilité de sejparer compeitence et choix de fa boi aplicable. objet de la competence et la compirence personnelle et recomaissance des inkmions despartis conme étant trois possibilites de rechunge que les Efats sans mariage covenam pewe'nt wiliser pow faire respecter les intentions des partis et lesprit du mariage covernant. Dans ke coss du Comada, I'anteur

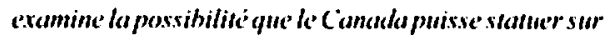
so compeitence a enfendre le cas sur la base dis

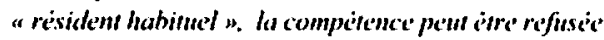
sur la base du tribunal qui ne convicut pas florum non conveniens) ou, encore, que la bi sur le mariage covenam diclare que la Dectaration d'intentionsigue" par les partis représente un article exprès de choix de loi applicable.

\section{TABle of CONTENTS}

I. INTROdUCTION ............................. 816

II. Distinguishing CHARACTERISTKCS OF:

Covenant Marriagie $\ldots \ldots \ldots \ldots \ldots \ldots \ldots \ldots \ldots \ldots . \ldots \ldots 17$

A. Fenture 1: Mandatory Premarital Counselling . . . . . . 817

B. Feature 2: Contractual. Obligation to Take

"Reasonable EfForts" to Preserve the Marriage ...... 818

C. FEATURE 3: RESTRICTED GROUNDS FOR DivorCE ......... 819

III. THE IMPACT OF CONFLICT OF: LAWS ON

Covenant Marriacif.s . . . . . . . . . . . . . . . . . 819

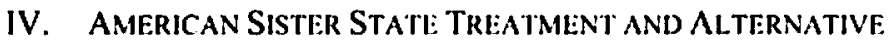

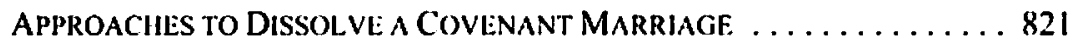

A. Current American Treatmfint of

DivorCE APPLICATIONS . .................. 821

B. Separating JurisDiction from Cioice of LaW ......... 821

C. Separatingi Subject MATter Jurisdiction

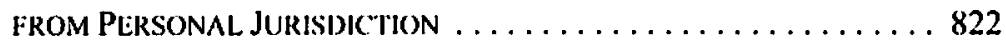

B. Comm (Honours), L.L.B. (Queen's (iold Medalist). The author is currently articling at Goodmans L.L.P in Toronto. The author wishes to thank Professor Martha Bailey for her supervision and assistance with this article. 


\section{RECOGNITION OF THE: "DECLARATION OF INTENT"}

AS A LEgally BINIING CONTRACT . .............. 823

E. Proposed Federal. Mecilanisms to affect Covenant

Marriage Legislation Between Sister States ........ 826

V. CANADIAN TREATMENT OF DISSOLVING A

CovenANt Marriage ......................... 827

A. Canadian Court's JuRisuiction to Hear Divorcle

APPLICATIONS: "ORDINARILY RESIDENT" REQUIREMIENT . . . . . 827

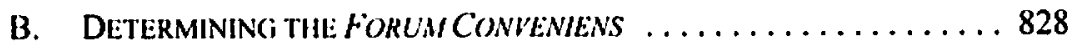

C. Stay of Procefdingis ..................... 833

D. ASSUMING JURISDICTION AND APPLYING THE

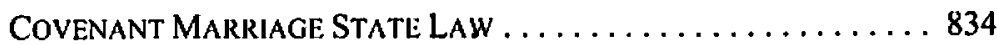

vi. Conclusion ............................ 835

\section{INTRODUCTION}

This article focuses on the effectiveness of covenant marriage, a new form of marriage recently introduced by three American states. It is important to recognize that the effectiveness of this form of marriage depends largely upon its treatment across borders. Where a spouse married under covenant marriage legislation seeks a divorce in a different state, the court's application of conflict of laws principles essentially advances or defeats both the intended purpose of the covenant marriage state's legislation and the couple's original intent in choosing to enter into a covenant marriage. In Part IV, this article compares the probable treatment of covenant marriages, as an American statutory creation, in American non-covenant marriage states with the potential treatment in Canada. This leads into an examination of alternative treatments available to sister states that would give effect to the purposes of covenant marriage.

In 1999, as a response to the rising American divorce rate, Louisiana became the first state to introduce covenant marriage as a new form of marriage that attempts to strengthen the commitment of couples entering into marriage. This provoked a majority of state legislatures to introduce covenant marriage bills. ${ }^{1}$ However, to date, only Louisiana, ${ }^{2}$ Arizona, ${ }^{3}$ and Arkansas ${ }^{4}$ have successfully implemented covenant marriage legislation. As the covenant marriage legislation of these states all share the same fundamental elements, this article focuses on Louisiana's legislation as being the first, and model, legislation for other states. The restrictions on divorce, the additional contractual obligations, and the legislated requirement of pre-marital counselling represent the defining features of a covenant marriage that distinguishes it from a standard marriage.

For a statc-by-state analysis of the legislatures' treatnuent of proposed covenant marriage bills, see Tony Perkins, "Covenant Marriage: A legislator's Perspective" (1999) 12 Regent U.L. Rev. 27. Sec also Kristina E. Zurcher, "'I Do' or 'I Don't'"? Covenant Marriage After Six Years" (2004) 18 Nolre Dame J.L. Ethics \& Pub. Pol'y 273. As recenlly as 2003, five states (Indiana, Texas, Utah, Virginia, and West Virginia) considered covenant marriage bills but did not pass them into law.

La. Rev. Stat. Ann. \$\$ 9:272-9:275.1 (West 2000) |Lomisiana Stature].

Ariz. Rev. Stat. Ann. $\$ \$ 25: 901-25: 906$ (West 2000 \& Supp. 2001).

Ark. Code Ann. $\$ \S 9: 11: 801-9: 11: 811$ (Michic 2002). 
Critics have highlighted numerous problems with covenant marriage including: it introduces a second tier of marriage that trivializes the current institution of marriage; it returns religion into the public sphere; and it possibly opens the door to the negative impacts of fault divorce that led to the shift to no-fault divorce. However, proponents have countered with compelling reasons and legal methods for non-covenant marriage jurisdictions to validly enforce the purpose of covenant marriages and its incidents. to honour both the choices that the parties made at the time of marriage and a covenant marriage state's legislative intent.

As divorce falls within state jurisdiction in the United States as compared to federal jurisdiction in Canada, the Amcrican treatment of covenant marriages differs from the Canadian treatment. Since each state typically applies its own laws to divorce petitions and the "Full Faith and Credit" clause constitutionally requires that states recognize a judgment by a sister state as valid," the enforceability of a covenant marriage's restrictive divorce provisions becomes problematic where one spouse establishes a domicile in a non-covenant marriage sister state to evade its restrictive divorce grounds. By contrast, Canada s federal Divorce Act sets out that a Canadian court can assert jurisdiction where one spouse has been ordinarily resident in the province for one year." Applying these principles, a covenant marriage divorce petition before a Canadian court has a greater likelihood of being returned to a covenant marriage state compared to one presented before a court in an American noncovenant marriage statc.

\section{The Distinguishing Cilaracteristics of Covenani Marriage.}

Louisiana's covenant marriage legislation provides an alternative for couples who wish to enter into a marriage that is different from a standard marriage in three significant ways. First, a couple secking to enter into a covenant marriage must receive counselling from a professional marriage counsellor who has a statutory duty to emphasize the seriousness of marriage. ${ }^{7}$ Second, the couple must sign a Declaration of Intent ("the Declaration") where the couple contracts, in this legally binding agreement, to take all reasonable efforts to preserve the marriage and agree to the application of Louisiana law. ${ }^{x}$ Third, the couple must acknowledge the specified fault-based grounds for divorce and the lengthened separation of two years required to obtain a no-fault divorce.

\section{A. Feature 1: Manidatory Premarital Counsellini;}

While the legislation does not set a time length requirement lor the premarital counselling, it outlines the content of the counselling requirements, including: (1) an emphasis on "the nature and purposes of marriage and the responsibilities thereto":" (2) "a discussion of the

s See U.S. Const, art. IV. \$ I staling that "Full Faith and Credit shall be given in each State to the Public Acts, Records, and Judicial Proceedings of every other State. And the Congress may by general Laws prescribe the Manner in whicl such Acts, Records and Proceedings shall be proved, and the Elfect thereof."

Divorce Act. R.S.C. 1985 (2⿺ Supp.), c. 3, s. 3.

, Lowisiana Stahte, supres note 2 at $\$ 9: 272$.

$\$ \quad$ bid. at $\$ 9: 273$.

$\quad$ bid. at $\$ 9: 272 . \wedge$. 
seriousness of covenant marriage"; 10 (3) a communication of the fact that a covenant marriage is a commitment for life;" (4) a discussion of the obligation to seek marital counselling in times of marital difficulties; ${ }^{12}$ and (5) a discussion of the exclusive grounds for "legally terminating a Covenant Marriage by divorce or by divorce after a judgment of separation from bed and board." ${ }^{\text {" }}$ Further, the section provides that this counselling may only be offered by a "priest, minister, rabbi, clerk of the Religious Society of Friends, any clergyman of any religious sect, or a professional marriage counselor."14

Aside from the emphasis on the seriousness of marriage as a commitment to the other spouse, the counsellor must provide couples with the informational pamphlet issued by Louisiana's Attorney General, which explains the terms and differences for grounds of divorce. This pamphlet is intended to make a couple entering a covenant marriage more informed of the legal consequences of marriage as compared to non-covenant marriage couples. ${ }^{15}$

\section{B. Featurf: 2: Contractuai. Oblightion to Take "Rfasonabl. EFForts" to Presfrye THE MArkIAGE}

Despite the widely held common law principle that many spouses' personal obligations are not subject to contractual modification, the Declaration signed by all covenant couples represents a state legislated exception. ${ }^{16}$ Professor Shaw Spaht, one of the drafters of the Louisiana covenant marriage legislation, asserts that the Declaration constitutes a legally binding contract between the parties to the effect that it meets the definition of contract in Louisiana's Civil Code as "an agreement by two or more parties whereby obligations are created, modified, or extinguished." "In the Declaration, a covenant couple agrees to undertake the significant obligation "to take all reasonable efforts to preserve [their] marriage, including marital counselling" in times of marital difficulties. ${ }^{\text {Ix }}$

Assuming that the effort to take all reasonable steps to preserve the marriage represents a contractual obligation, contract law principles apply to its performance. Therefore, this may trigger a duty to perform the obligation in good laith, subjecting "reasonable efforts" to a contract interpretation approach where steps could either fall short or go beyond marital counselling. As the legislation does not provide any remedy for a failure to honour this obligation, Professor Shaw-Spaht argues that this absence reflects the legislature's intent to enforce the obligation through contractual remedies.

\footnotetext{
10 Hoid. at $\$ 9: 273 . A(2)(a)$.

$" \quad$ lbid. at $\$ 9: 273 . A(1)$.

12 Hid.

1 Ihid. at $\$ 9: 273.1 .8$.

is Ibid. at $\$ 9: 273 . A(2)(a)$.

is Ihid. at $\$ 9: 273 . A(2)(b)$.

th See Part IV.D. below, for further discussion surrounding the en forceability of the contractual component of covenant marriages.

1) La. Civ. Code, art. 1906 (West 1987). See Katherine Shaw Spaht \& Symeon C. Symeonides, "Covenant Marriage and the Law of Conflict of Laws" (1999) 32 Creighton L. Rev. 1085 at 1091-97. 
The Declaration also includes what could possibly be interpreted as a choice of law clause where the parties agree that they "declare that [their] marriage will be bound by Louisiana law on Covenant Marriages."19 Extending the assertion that the commitment to "take all reasonable efforts to preserve the marriage" represents a binding contractual term, this application of Louisiana law arguably represents a binding choice of law clause. ${ }^{20}$

\section{Feature 3: Restricted Grounds For Divorce.}

Covenant marriage combines fault grounds with a no-fault possibility that is more difficult to meet than in a standard marriage. As a consequence of signing the Declaration, covenant spouses agree to adhere to these fault grounds and the restriction on their right to pursuc a "no-fault" divorce. Covenant marriage legislation permits divorce on the following legislated grounds: (1) where a party proves fault in the nature of adultery; (2) conviction of a felony and a sentence of imprisonment at hard labour or death; (3) abandonment for one year; (4) physical or sexual abuse of a spouse or child of one of the spouses; or (5) habitual intemperance or cruel treatment. ${ }^{21}$ However, the legislation permits "no fault divorce" after proof of living separate and apart for two years, ${ }^{22}$ a significantly greater time than the six months required to dissolve a standard marriage. Lastly, covenant marriage legislation offers the innocent spouse a unique option of pursuing a legal separation over a divorce. ${ }^{23}$

\section{ThE IMPACT OF CONFLICT OF LaWS ON CONENANT MARRIAGES}

The effect and purpose of covenant marriages greatly depends upon its potential treatment in non-covenant marriages states because the essence of covenant marriage - to promote the strengthening of marriage - comes from its restrictive grounds for divorce and the contractual obligation on spouses to make reasonable efforts to preserve the marriage. Therefore, if a spouse can avoid these restrictive grounds by crossing the border into another state, these fundamental means of advancing the purpose of covenant marriage are lost. Thus, where a state chooses to apply its own state law to a divorce petition, several problems arise. First, it introduces the possibility for the return of "migratory divorce," which resulted from California's introduction of no-fault divorce in the 1960s. This forum shopping resulted as spouses began migrating to states with the most favourable divorce laws, pressuring all states to eventually converge and form today's relatively uniform divorce law. Professor Bix effectively summarizes the problem of allowing states to apply their own divorce law:

Allowing cours to apply their own states ' dissolution standards, regardless of the statute-based expectations or agreements of the parties at the time of marriage only encourages opportunistic reneging on those expectations and agreements ... [which] in turn will reduce partics' abilities to marry on terms that are optimal both for themselves and for society generally. ${ }^{24}$

ibid.

Sec Part IV.D, below, for further discussion surrounding the binding eflect of this choice of law clatuse. Lomisiana Statule, supra note 2 at \$9:307.^(1)-(4).

lbid. at $\$ 9: 307 . A(5)$.

lbid. at $\$$ 9:307.B. This section also highlights the different set of requirements that apply for obtaining a legal separation instead of a divorce.

Brian H. Bix, "Choice of Law and Marriage: A l'roposal" (2002) 36 Fam. L.Q. 255 at 265. 
Second, the application of forum law results in the loss of a covenant marriage state's legislative intent to create a unique marital regime for its citizens.

Third, an application of a state's own law to a covenant marriage divorce application jeopardizes a spouse's ability to rely on the terms he/she entered into at the time of marriage, which introduces a level of uncertainty into the relationship. Applying forum law to a covenant marriage divorce petition introduces an element of unpredictability because a spouse does not expect the rights and obligations obtained when he/she married under one regime to change by one spouse moving to another state. The Louisiana Court of Appeal's reasoning in $\mathrm{We} / \mathrm{s} / \mathrm{h} \mathrm{v}$. Wels $/ \mathrm{h}^{25}$ illustrates the court's unwillingness to apply a set of rules that are different from the marriage regime entered into by the spouses. In that case, the Court held that a wife who was married 20 years before covenant marriages were created was not entitled to the same divorce limitations in covenant marriages because the statutory definition in the legislation under which she was married was different. Extending this reasoning to a spouse that intends to avoid the elements of the covenant marriage regime into which he/she entered by moving to another state, the application of forum law essentially allows this undesirable ability for a spouse to dissolve his/her marriage under a regime not contemplated or agreed upon by either party at the time of marriage.

Fourth, the application of forum law reintroduces the unjust phenomenon that arose during the period of migratory divorce where wealthier couples could obtain divorces on relaxed grounds because they could afford to travel across state borders. Professor Leflar explains this problem:

Socially and sociologically, there have been two sets of grounds for divoree in the law of a conservative divorce state, one written officially in its own lawbooks and the other available under its conflicts rules to local spouses who could atlord the expense and inconvenience of going to an easy divorce state to file suit. ${ }^{26}$

The extent of the phenomenon's impact on covenant marriage remains unclear as debate surrounds whether covenant marriage couples represent a wealthier portion of the population as compared to those that enter into standard marriages. Sociologists recently gathered data from 538 newlywed couples under the regime as compared to those that entered standard marriages in that year to test this antecedent. ${ }^{27}$ Their research supported the majority of their hypotheses that covenant marriage partners are more educated, hold more traditional attitudes, and have a greater tendency to choose communicative conflict resolution strategies. However, their findings did not support their expectation that these couples were less likely to have material debts. In fact, it revealed that these covenant marriage couples were no richer than the standard married couples. ${ }^{28}$

Lastly, a state's application of forum law does not give appropriate weight to a couple's choice to select a regime they feel would best govern their relationship and serve their interests. Therefore, the next Part examines the current treatment of divorce in the United

$\because \quad 783$ So.2d 446 (La. App. 5 Cir. 2001).

: Rohert A. Leflar, Luther L. MeDougal III \& Robert L. Felix, American Conficts Law, 4th ed. (Charlotlesville, Virg.: Michie, 1986) at 614.

$\because \quad$ Steven Nock el al., "Covenant Marriage Tums Five Years Old" (2003) 10 Mich. J. Gender \& L. I69. 
States and the alternative treatments available to sister states that would give effect to covenant marriage dissolution requirements.

\section{AMERICAN Sister State TrEatMent and Al.ternative Approaches to Dissolve a CovenaNt Markiage}

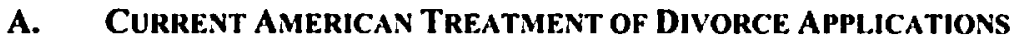

Prevailing American practice and accepted constitutional doctrine indicates that sister states will apply forum law to petitions to dissolve a covenant marriage. Generally, a state has the jurisdiction to decide a divorce application where one of the spouses is domiciled in that state, regardless of where the marriage was celebrated. ${ }^{29}$ Since Williams $v$. North Carolina ${ }^{30}$ where the United States Supreme Court held that a forum state had jurisdiction over divorce and was free to apply its own divorce law, courts have consistently taken jurisdiction over divorce proceedings and have applied the forum state divorce law. As a result, when deciding upon choice of law, American courts almost automatically find that domicile represents the determinative connecting factor. ${ }^{31}$ However, this convention does not take into account the fact that the decree-granting state may have rules that are radically different from the rules in effect at the time and place where the parties married or where they lived most of their married life. Therefore, the following three methods may provide possible alternatives for sister states to give effect to a state's covenant marriage regime.

\section{B. SEPARATING JURISDICTION FROM CIIOICE OF LAW}

A state's jurisdiction to grant divorce does not necessarily obligate a state to apply its own law. Therefore, separating the choice of law issue from the grant of jurisdiction signifies the first step that a sister state may take to give effect to a covenant marriage. By accepting jurisdiction over the divorce proceeding yet choosing to apply the law of the covenant marriage state, a sister state retains jurisdiction over its new resident while enforcing a spouse's previous commitments. Judge Hastie, dissenting in Alton $v$. Alfon, first advanced the argument for separating choice of law from jurisdiction in a divorce proceeding. ${ }^{32} \mathrm{He}$ argued that "under correct application of conflict of laws doctrine, and even under the due process clause, it [may be] incumbent upon the Virgin Islands, lacking connection with the subject matter, to apply the divorce law of some state that has such connection." the United States Supreme Court never heard this argument proposing the separation of jurisdiction from choice of law in divorce proceedings because the parties obtained a divorce in their matrimonial state and the case became moot.

The American Law Institule, Restatement of the Law, Second: Complict of Lens 2d, vol. 1 (St. Paul, Minn.: American Law Institute Publishers, 1971) $\$ 70-72$ [Restoucme'ms. vol. 1].

317 U.S. 287 (1942).

Peter Hay, "The American "Covenant Marriage' in the Confliet of Laws" (2003) 64 La. L. Rev. 43 at 52.

207 F.2d 667 (3d Cir. 1953).

lbid. at 685 . 
Adding to the uncertainty surrounding the separation of jurisdiction from choice of law, the Restatement sets out that " $[t]$ he local law of the domiciliary state in which the action is brought will be applied to determine the right to divorce." ${ }^{4}$ However, this unqualified statement does not take into account the significant consideration that another state, such as the former matrimonial state, may have a closer connection to the marriage than the new state, especially when a spouse and/or children continue to live there. While separating subject matter jurisdiction and personal jurisdiction in divorce goes against established case law in the United States, this approach has a greater chance of success in Canada where a court considers common law contlict of laws principles in determining whether to accept jurisdiction over divorce proceedings. ${ }^{35}$

\section{Separating SUbJect MATTER JURISDICTION From Personal JuRisDiction}

In order for a court to take jurisdiction over a divorce, a court must have both personal and subject matter jurisdiction. Domicile typically fulfills the basis for personal jurisdiction over the issue in a divorce proceeding. Meanwhile, subject matter jurisdiction asks whether a court has the power to grant a divorce or dissolve a marriage. Therefore, a spouse may choose to challenge a non-covenant marriage state's subject matter jurisdiction by arguing that it lacks the jurisdiction to grant a divorce for a marital regime unknown to its laws.

Recently, the Connecticut Appellate Court considered this issue in Rosengarten v. Downes where it declined a petition for the dissolution of a Vermont civil union on grounds that it lacked subject matter jurisdiction to decide the matter. ${ }^{36}$ The Court held that it lacked subject malter jurisdiction because it only had the power to dissolve marriages, not other types of unions unknown to Connecticut law. By extension, a covenant marriage may represent a union different from a standard marriage unknown to the laws of sister states. As such, those states lack the subject matter jurisdiction to decide upon the dissolution of the covenant marriage. The unique option to obtain a legal separation instead of a divorce to dissolve a covenant marriage advances the argument that the union is unknown to sister states.

However, in focusing on the significant differences between a civil union and a standard marriage, the Court found that it lacked subject matter jurisdiction to dissolve the civil union. In light of the similarities between a covenant marriage and a standard marriage, it may be more difficult to make the parallel argument that a sister state lacks subject matter jurisdiction over covenant marriages. ${ }^{37}$ As a covenant marriage represents a state legislature's intent to create a union between heterosexuals, conferring the same rights and status as couples in a standard marriage, a covenant marriage appears far closer to a standard matriage than a civil union. Further, the Court in Rosengarten noted that the Vermont state legislature made its intention clear to treat a civil union as something other than a marriage by introducing the civil union as a response to the Vermont Supreme Court's holding that

The American Law Institute, Restatement of the Law: Second: Conflict of leaws 2 d, vol. 2 (St. Paul, Minn.: American Law Institute Publishers, 1971) \$ 285 [Restatemen, vol. 2].

See Pan V.B, helow, for lurther discussion surrounding the determination of formem comenicns.

802 A.2d 170 (Conn. App. 2002) [Rosengarren].

Hay. supra note 31 at 51 . 
denying marriage to same-sex couples was unconstitutional. ${ }^{3 s}$ Absent any such clear intention by covenant marriage state legislatures indicating that a covenant marriage represents a choice other than marriage unknown to sister states, the states likely have the subject matter jurisdiction over such divorce applications. In particular, the American choice of law rule that a marriage valid where celebrated will be recognized as valid elsewhere indicates the non-covenant marriage state has jurisdiction to decide the divoree procecdings brought by a petitioner domiciled there. ${ }^{\text {io }}$

\section{RECOGNITION OF THE "DECLARATION OF INTENT" AS A LEGall.y BINdiNG; CONTRACT}

\section{ThF. EffF.t Of The Legislated Choice of Law Clause}

As mentioned previously, the Declaration required by covenant marriage legislation represents a legally binding contract and contains what may be interpreted as a choice of law clause. Both parties sign the Declaration that "declare[s] that [their] marriage will be bound by Louisiana law on Covenant Marriages," representing their express choice of the validating law that underlies the parties' commitment. However, it is important to note that this choice of law clause does not necessarily represent a choice of forum. It indicates to a sister state that the parties intend to be bound by Louisiana's covenant marriage law, but not necessarily to the forum of the covenant marriage state. While this legislated contractual choice of law clause neither obligates a sister state to apply the covenant marriage state laws nor changes a sister state's jurisdiction over divorce applications brought by those domiciled in its state, it supports the option available for sister states to apply the law of the covenant marriage state as it evidences that the parties turned their mind to the issuc. Al a minimum. this clause signals to the covenant marriage state that a party expects to be bound to the covenant marriage state's law in an application for divorce. It also advances the argument that a covenant marriage more closely resembles a commercial contract than a standard marriage, making the commercial contract application of conflicts principles a viable option.

\section{Triating Covenant Marriage's Choice of Law Clause as a Commircial Contract Clause}

It remains as true today as it did in the last century that marriage "is something more than a mere contract. ${ }^{.+11}$ Courts continuously recognize that a marriage contract differs from an ordinary commercial contract because parties are not entitled to mutually bargain away interests involved in marriage because the contract involves more than the two parties making a contract; it concerns spouses, the government, the families of the married couple, and children involved in the marriage. To this effect, while a court preserves freedom of contract in commercial agreements, it does not treat a marriage contract in an identical fashion." Thus, where partics to a commercial contract agree to a choice of law clause. the court gives effect to this. However, where parties to a marriage contract agree to a choice of 
law, a change in domicile becomes the determinative factor in choosing what law to apply based on the state's policy interests in the marital status of its citizens. Commentators suggest that this ironically results in courts giving less deference to a party's choice in a subject matter that concerns one's individual preference and affects one's happiness in a way more deep and profound than most commercial transactions ever could. ${ }^{\text {t3 }}$

The Declaration superimposes an additional contractual element on the traditional marriage contract, which further advances that a covenant marriage more closely compares to a commercial agreement than a standard marriage. By choosing a covenant marriage, parties make a voluntary and informed choice to assume obligations beyond the basic option to marry. As the voluntariness of the marriage contract and the relative bargaining power of the parties represent a few of the reasons for the different treatment of marriage contracts as compared to commercial agreements, the legislated requirements address these concerns to the extent that parties give their voluntary informed consent following detailed pre-marriage counselling. Compared to a standard marriage where couples marry at varying levels of knowledge surrounding the legal incidents and status of marriage, those that enter into a covenant marriage receive thorough pre-marital counselling that explains the seriousness and legal consequences of the type of marriage into which they are entering.

A couple married under covenant marriage legislation signals that it intends to take on obligations over and above the basic option to marry, arguably attracting the conflict of laws treatment given to commercial contracts over the treatment given to standard marriages. In a commercial contract, a party who seeks to defeat the application of the choice of law clause must show that the chosen state has no substantial connection to the parties and that there is no other reasonable basis for the parties' choice or that the application of the law of the state would be contrary to a fundamental policy of a state that has a materially greater interest. ${ }^{\text {th }}$ Thereforc, if a court applied ordinary commercial contract principles to the covenant marriage, the Declaration's choice of law clause would stand a greater chance of being enforced as the covenant marriage state would have the "substantial relationship" to the parties, with a sister state's stance that covenant marriages are contrary to the state's fundamental policy being unlikely to succeed. ${ }^{\text {ts }}$

However, treating a covenant marriage as a commercial contract triggers a host of public policy concerns that have long surrounded the private contracting of marriage. Even proponents of covenant marriage have objections to treating covenant marriage as a mere contract in order to advance its enforcement by sister states. First, commentators argue that it devalues marriage to a simple contract. By allowing private contracting in marriage, this introduces the possibility for parties to give themselves to marriage in limited extents, choosing the higher commitment of covenant marriage or a lesser commitment in a standard marriage. Second, since marriage is a legally recognized status that displays a public, legal commitment, a mere private contract that can be casily changed by the parties does not serve as an adequate comparison. By conferring status, the government attaches certain rights and

4 Sec Bix, stupra note 24 at 255.

4 Restatement, vol. 1, supra note 29 al $\$ 187(2)$.

4. Shaw Spaht \& Symeonides, stupra note 17 at $1111-13$. 
obligations such as tax liability and medical responsibility to marriage, which further highlights the imperfect comparison of marriage to private contracting. ${ }^{\text {to }}$

\section{Covenant Marriage. Contract Protects InCIDENTS of Marriage and Provides Rf.medial. Relief}

Even if a sister state applies forum law to dissolve a covenant marriage, the contractual provisions of covenant marriage affect the determination of the incidents of marriage. The Declaration may require that the matrimonial state law govern incidents of marriage including spousal and child support, and distribution of marital property. The United States Supreme Court in Vanderbilt v. Vanderbild $r^{7}$ confirmed that differing jurisdictional rules allow for the possibility of "divisible divorce," where one court has the power to dissolve the marriage but does not have the power to finalize the obligations of the parties. Courts may set financial obligations only when they have personal jurisdiction over both parties. Therefore, covenant marriages retain some of their effect by allowing the covenant marriage state to finalize the obligations of the party even when a sister state applies forum law to a divorce petition and dissolves the marriage.

However, the possible interpretation of the Declaration having a choice of law clause has a higher likelihood of enforcement involving the financial determinations because it does not directly relate to the ultimate question of a couple's marital status. Even in the event that a court does not interpret the Declaration as containing a choice of law clause, the covenant marriage state's interests in the incidents of marriage compared to the forum state's interests favour the application of the covenant marriage state's law. ${ }^{48}$

Assuming the obligation "to take all reasonable steps to preserve marriage" contained in the Declaration reflects a contractual undertaking, a spouse's attempt to circumvent the restrictive divorce grounds by obtaining a judgment from a sister state under its divorce laws represents a breach of this obligation. This triggers an ordinary breach of contract and remedies analysis. In assessing these damages, contract principles indicate that a breach of contractual obligations entitles the non-breaching spouse to both pecuniary and nonpecuniary damages. While an ordinary contract remedy typically involves the award of monetary damages, courts also consider equitable relief where monetary damages are insufficient. Applied to covenant marriages, where a sister state applies forum law to a covenant marriage divorce application, it removes the opportunity for equitable relief, leaving a non-breaching spouse with an empty contractual claim when moncy damages are inadequate. While specific performance remains within the discretion of the courts, a covenant marriage state must respect a sister state's divorce decree pursuant to the "Full Faith and Credit" clause. ${ }^{+9}$ Even in the alternative situation where a divorce has not been

th Zurcher, sipura note 1.

t) 354 U.S. $416(1957)$.

sx The marriage state's interest only offers additional strength to the main reason that the couple made the conscious choice of entering inlo a covenant marriage over a regular marriage where it had the option of either form. This ability to choose the form of marriage differentiates the covenant marriage situation from spouses who wish to seck a divorec in Canada from a conservative form of marriage centered into outside of Canada where the divorcing spouse had no altemative to the consenative form of marriage. For further analysis of the "Full Faith and Credit" clause, see supra note 5 and accompanying text. 
obtained, ordering marriage counselling to reconcile a couple where one party has already refused to comply with the obligation seems counter-productive. Therefore, a spouse may seck both tangible and intangible monetary damages to compensate for the other's breach in obtaining a divorce from a sister state that can range from the extra cost of maintaining an extra household during the time where counselling would have taken place, to damages for the embarrassment, mental anguish, humiliation, or psychological damages suffered as a result of the breach. 50

\section{E. Proposed federal Mechanisms to Affect Covenant Markiage Legislation Between Sister States}

In light of the application of forum law to determine a divorce petition of a covenant marriage, commentators have suggested two potential actions available to Congress that would enforce the purpose of covenant marriage without straying from established conflict of laws principles. ${ }^{51}$ First, Congress may pass a law requiring that "the grounds for divorce that are effective in the couple's domicile at the time of execution ... be honoured by other states." "2: This strikes a balance between enforcing the covenant marriage state's legislative intent, and allowing a sister state to retain jurisdiction over its new domiciliary and to apply its fonım law in other respects. Second, Congress can choose to mandate that states must give "Full Faith and Credit" to the domestic relations law of the state where the marriage was contracted at the time it was celebrated. ${ }^{53}$ However, this option faces two significant challenges. First, the interpretation of the "Full Faith and Credit" clause has only been extended to respecting sister state judgments, rather than to sister state laws. ${ }^{54}$ Second, substantive due process guarantees arise where the rule would preclude an individual's opportunity to remarry." While statutes barring individuals from marrying or remarrying raise due process concerns, covenant marriages arguably do not trigger such concerns because convent marriages still permit divorce, albeit under more restrictive grounds.

However, these suggested Congress passages face potentially significant challenges from the sister states that may oppose them. Since the right affected represents an impact on status and alters a right to divorce, the passages must meet the test set out by the United States Supreme Court in Zablocki, Milwaukee County Clerk v. Redhail. ${ }^{56}$ In Zablocki, the Court held that when a "statutory classification significantly interferes with the exercise of a fundamental right, it cannot be upheld unless it is supported by sufticiently important state inlerests and is closely tailored to effectuate only those interests." ${ }^{37}$ Therefore, sister states may argue that imposing the requirement to recognize the restrictive grounds of divorce of another state violates its interest in regulating marriage and is not supported by the covenant marriage state's "sufficiently important state interests." In light of the importance that the

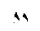

in

Shaw Spaht \& Symeonides, supra note 17 at 1089.

See Mark Strasser. "Baker and Some Recipes for Disaster: On DOMA. Covenant Marriages. and Full Faith and Credit Jurisprudence" (1998) 64 Brook. L. Rev. 307 at 347.

Ibid. at 346. quoting Eric Rasmusen \& Jeffrey livans Stakc. "Lifting the Veil of Ignorance: Personalizing the Marriage Contract" (1998) 73 Ind. L.J. 453 at 499.

Ibid. at 348 .

Hiid.

Ihid.

434 U.S. 374 (1978) [Zablocki].

Ibid. at 388. 
United States Supreme Court has given to the freedom to marry, holding that it is "one of the vital personal rights essential to the orderly pursuit of happiness," $9 k$ a sister state may legitimately challenge any potential passages by Congress on the basis that upholding a restriction on the right to divoree represents a significant interference of a fundamental right, not sufficiently tailored to affect the interests of a covenant marriage state.

\section{Canadian Treatment of Dissolving a Covenant Marriage:}

\section{A. Canadian Court's Jurisdiction to HFar Divorcl: APPLICATIONS: "ORDINARILY RESIDENT" REQUIREMIENT}

The Divorce $A c t, 1985$ confers jurisdiction on a Canadian court "to hear and determine a divorce proceeding if either spouse has been ordinarily residemt in the province for at least one year immediately preceding the commencement of the proceeding." "si The "ordinarily resident" requirement signifies a shift from the previous $\mathrm{Act}$, which allowed courts greater freedom to apply common law conflict of laws principles to the choice of law issuc and to determine the form convenichs. "The Manitoba Court of Appeal in Kornberg v. Kormberg." discussed below, explained that this jurisdiction flows from the exclusive legislative authority of Parliament to decide matters of marriage and divorce and that this jurisdiction to hear and determine divorce proceedings has been given to the superior courts and provinces by Parliament. ${ }^{62}$

Since the term "ordinary resident" is not defined in the Divorce Act. courts have developed common law interpretations of "ordinarily resident." generally holding that it is a question of fact, independent of citizenship, domicile, or immigration status. " $A$ person may become "ordinarily resident" the day he/she arrives if he/she has the intention of making a home in that province for an indefinite period of time." $A$ pplying this to a covenant marriage situation, a spouse who enters Canada and becomes "ordinarily resident" the day he/she enters Canada may commence a divorce proceeding from the covenant marriagc one

¿. Loving v. Virgina, 388 U.S. 1 at 12 (1967).

59 Diverce Act, supra note 6. s. 3(1) [cmphasis added].

w Previously, the Divorce Act. R.S.C. 1970, c. 1)-8, required that a spouse was domiciled andior hat established actual residence.

"1 (1990), 70 Man. R. (2d) 182 (C.A.) [Kornherg].

a. $\quad$ bid. at 190.

63 Janet Walker \& Jean-Gabricl Castel. Comodion Conflicl of Laws, Gth ed., 2 vols., lowseleal (Markham, Ont: LexisNexis. 2005) vol. 2 at $\$ 17.1$ (b). Sec also.Jemkins v: Jemkins (2000). 8 R.F.L. (5th) 96 (Ont. Sup. Ct. J.).

ot Sec. WacPherson v: .MacPherson (1976). 70 D.L.R. (3d) 564 at 570 (Ont. C.A.) [.Mfoc.Pherson]. where Evans J.A. held: "In my opinion. the arrival of a person in a new locality with the incention ol making a home in that locality for an indefinite period makes that person ordinarily resident in that community." Further, Evans J.A. adopts the Fnglish analysis of "ordinarily resident" at 567 : "Ordinary residence is a thing which can be changed in a day. $A$ man is ordinarily resident in onc place up till a particular day. He then cuts the connection he has with that place -.. - in this case he left his wife" (citing Macror:

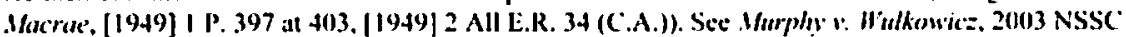
181. [2003] N.S.J. No. $324(\mathrm{QL})$ where Mac/herson was recenly followed in the application of the current Divorce Act. Sec also Himer v: Himer (1996) 23 R.J.L. (4th) 401 (Ont. Gen. Div.) where the Court held that an intention to return or to remain indefinitely may be the decisive factor in determining which place is the ordinary residence. 
year later, and therefore circumvent the two year separation requirement and legislated obligation to undertake reasonable efforts to preserve the marriage.

In Alexiou v. Alexiou, ${ }^{65}$ Nash J. reviewed the jurisdiction of a Canadian court to determine a husband's divorce application and corollary relief where the wife sought to have the matter tried in a Minnesota court instead of in a Canadian court. Examining the jurisprudence surrounding "ordinarily resident," the Court determined that consideration must be given to "whether a person has established a home, employment and a social life in a particular locale which would indicate an intention to continue a regular and customary mode of life there."

In Alexiou, the Court extended the test set out by the Supreme Court of Canada in Thomson v. M.N.R., ${ }^{67}$ which determined "ordinarily resident" in an income tax matter to interpret the same term used in the Divorce Act ${ }^{68}$ This test sets out that the determination of "ordinarily resident" is "a matter of the degree to which a person in mind and fact settles into or maintains or centralizes his ordinary mode of living with its accessories in social relations, interests and conveniences at or in the place in question." ${ }^{169}$ Applying this test, the Court concluded it had jurisdiction to hear the divorce application as Mr. Alexiou had, in mind and fact, settled in Canada by having obtained employment, established a social life, and purchased a home..$^{70}$ Interestingly, Nash J. held that the husband's temporary visitor's visa status did not affect the determination of Mr. Alexiou's "ordinarily resident" status." Determining that although it had jurisdiction to hear the application, the Court declined jurisdiction to determine the divorce proceedings because it found that the balance of factors in determining formm conveniens, as discussed below, favoured the foreign courts in exercising jurisdiction. ${ }^{\text {? }}$

\section{B. Determining the Forum Conveniens}

\section{1. "Clearly or Distinctly MORE APPROPRIATE ForUm" Test}

Despite the ability to take jurisdiction on the "ordinarily resident" basis, Canadian courts have consistently declined to exercise the jurisdiction to determine divorce applications where a forum outside Canada is more appropriate. The Supreme Court of Canada in Amchem Products Inc. v. British Columbia (Workers' Compensation Board) ${ }^{73}$ set out the guiding principles to determine whether Canada represents the forum conveniens or whether a more appropriate forum outside Canada exists:

The choice of the appropriate forum is still to be made on the basis of factors designed to ensure, if possible. that the action is tried in the jurisdiction that has the closest connection with the action and the parties and

(1996), 188 A.R.149 (Q.B.) [Alexiou].

Jbid. at para. 30.

[1946] S.C.R. 209 [Thomson].

Alexious, supra note 65 at para. 27.

Thomson, supra note 67 at 225 [emphasis added].

Alexiou, supra note 65 at para. 31.

Jbid. at para. 32.

lbid. at paras. 37-59.

[1993] I S.C.R. 897 [Amchem]. 
not to secure a juridical advantage to one of the litigants at the expense of others in a jurisdiction that is otherwise inappropriate. I recognize that there will be cases in which the best that can be achieved is to sclect an appropriate forum. ${ }^{74}$

Courts have since outlined several of these factors specific to divorce proceedings. The Manitoba Court of Appeal in Komberg explained that the test for determining the "clearly or distinctly more appropriate forum" 75 in divorce proceedings requires both regard for the interests of all the parties and the ends of justice. ${ }^{76}$ In order to balance the interests of all parties, the responding spouse must "not just ... show that [Canada] is not the natural or appropriate forum for the trial, but to establish that there is another available forum which is clearly or distinctly more appropriate than the [Canadian] forum." The Coun considers several factors including: (1) evidence that connects the case to the forum; (2) the presence of children; (3) whether jurisdiction is founded as of right; and (4) whether any personal and juridical advantages may indicate a clear or distinctly more appropriate forum. ${ }^{\text {is }}$

Generally, "[i]n deciding which of two jurisdictions olfers the more convenient forum, the court should ordinarily consider which jurisdiction can deal more comprehensively with the issue before the court."79 In Kornberg, this required the Court to decide whether Manitoba or Minnesota could more comprehensively deal with the dominant issues ol discovery, valuation, and disposition of the couple's substantial commercial assets since the parties filed an application for division of matrimonial property along with the petition for divorce. Applying this general principle to covenant marriages, the covenant marriage state arguably represents the more convenient forum because it can deal more comprehensively with the dissolution of a marital regime created by its own statc legislature than a foreign court that neither offers a comparable regime nor has ever been confronted with such a system.

\section{Personal and Juridical advantage}

Personal and juridical advantage assesses whether injustice would result to a spouse if the other spouse were permitted to proceed in a foreign court. This considers whether the proceedings in the foreign court would be vexatious or oppressive, or whether an injunction restraining a spouse to continue proceedings would result in an injustice to him/her. ${ }^{* 0}$ The Ontario Court of Appeal in Nicholas $v$. Nicholas ${ }^{81}$ subsequently considered the appropriate method used to determine whether declining jurisdiction in a divoree proceeding would result in personal or juridical disadvantage. The Court approved the approach used by the motion judge for determining juridical disadvantage, whereby she compared the family law regimes in the two jurisdictions (based on expert opinions on Trinidadian law concerning the issues) to find that no juridical disadvantage would result by returning the divorce proceedings to

"3. The Court adopted this test from Spiliade Merritime Corp. :. Comsulex Lad., [1987] 1 A.C. 4 (60) (II.I..) [Spilisode].

io Kornherg. suproa nolc 61 at 186.

$" \quad$ bid. at 187, quoting Spiliada, supra note 75 at 477.

is Kornberg, ibid. at 186.

:9 lbid. at 189.

$\$ \quad$ lbid. at 187.

s1 (1996), 139 D.L.R. (4th) 652 (OnI. C.A.) [Nicholas]. 
Trinidad and Tobago. ${ }^{82}$ Having found that Trinidad "shares the same universal principles of this jurisdiction [Ontario]," together with the strong possibility that the Trinidadian court could come to results similar to those reached in Canada, the Court approved the motions judge's finding that the wife would not suffer any juridical disadvantage in proceeding in the foreign jurisdiction. ${ }^{\mathrm{K} .3}$

Extending the Court's reasoning to covenant marriages, expert opinions regarding the covenant marriage regime may be introduced to determine whether a covenant marriage spouse would suffer juridical disadvantage by returning the divorce application to a covenant marriage state. As neither spouse would likely face "vexatious or oppressive" treatment in a covenant marriage state court, it is unlikely that this personal and juridical disadvantage factor would present a barrier to returning a covenant marriage divorce application to a covenant marriage state. Further, the family law regime of any covenant marriage state largely shares the same universal principles of those in Canada. While a strong possibility does exist that a covenant marriage state could reach results different from those reached in Canada, a finding that enforces the expectations of both the state and the parties when they entered into the marriage, and upholds the contractual obligation that the applicant spouse made at that time, does not represent an injustice to cither party.

\section{EVIDENCE CONNECTING THE CASE TO TIIE FORUM}

The evidence connecting the case to the forum represents a heavily fact dependent consideration. In each of Nicholus, Kornberg, and Alexiou, the court's determination that the bulk of the couple's commercial assets and marital property remained in the foreign jurisdiction as compared to the couple's assets in Canada significantly influenced the decision to decline jurisdiction over the divorce proceedings, especially where the divorce petition included an application for corollary relief. Therefore, depending on the facts surrounding a couple married under covenant marriage legislation and whether one spouse remains in the covenant marriage state, with the majority of the couple's assets in that state, a Canadian court may likely decline to exercise jurisdiction. Evidentiary concerns become especially determinative where children are involved.

\section{THE IMPACT OF THE "BEST INTERESTS OF THE CHILDREN" PRINCIPII: ON FORUM CONIINIINSS}

Where children are involved, the Divorce Act mandates that the court must satisfy itself that reasonable arrangements have been made for the support of the children of the marriage before finalizing any divorce petition. ${ }^{x+4}$ This legislative direction given to courts applies to deciding jurisdiction over a divorce petition and represents the elevated status given to a child's residence for determining where proceedings will be litigated. ${ }^{35}$ Professor BissettJohnson advances that this elevated status "supplant[s] such concepts as 'forum conveniens,'

Hoid. at 6.56.

sid

st Sipro nole 6, s. I I ( ) (b)

s5 $\quad$ Alastair Bissetl-Jolunson \& David C. Day, The New Divorce Law: A Commentary on the Divorce Act, 1985 (Toronto: Carswell, 1986) at 42. 
'domicile' and 'ordinary residence' ... with the criteria of the child's 'most substantial connection' where parenting relief is sought in a proceeding under the new Divorce Act."

The Court in Alexiou highlighted the importance of declining jurisdiction over a divorce petition where a superior forum exists to determine the best interests of the children because "custody and child support should be heard and determined in the same forum unless there is a bona fide reason for the issues to be divided." ${ }^{\text {in }}$ In addition, the Court added the following factors as relevant for determining the fortm comveniens for divorce proceedings where children are involved: (a) the location of witnesses, such as relatives, friends, and teachers; (b) the location where the parties have lived and worked the majority of their lives; and (c) the location where the evidence will be readily available to bring the matter to a quick and final determination. ${ }^{\mathrm{s}}$

Courts readily decline jurisdiction to determine divorce proceedings in cases where children reside outside the jurisdiction. In Durairaj v. Durairaj, ${ }^{, 9}$ the Court held that the fortum comeniens was India because it contained the best evidence available concerning the circumstances of the child. In this case, the marriage took place in India, where the child continued to remain as resident with his mother. while the father filed for divoree in Alberta. The Court dismissed the divorce application on the basis that since the child lived with his mother in India, attended school, and had family and friends in India, the best evidence concerning his circumstances was in India."

Therefore, where children are involved in a covenant marriage, the "best interests of the children" principle operates to suggest that a Canadian court may decline jurisdiction to hear the divore petition where the best evidence involving the children's interest remains in the covenant marriage state.

\section{JURISDICTION AS OF RIGIIT}

Jurisdiction as of right, where a court has personal jurisdiction over a defendant and the right to serve the defendant with the process is unqualified, does not alone determine a clearly and distinctly more appropriate forum. Where jurisdiction exists as of right. the Alberta Court of Appeal in United Oilseed Products Lid. v. Royal Bank of Camalda held that "[e]ven where that jurisdiction exists as of right we should recognize that there may be a superior forum, having regard to the interests ol both parties. Where that superior forum can be readily identilied litigation should be pursued in it." Justice Nash in Alexiou applied these comments involving a commercial contract to find that the fortum comeniens in a family context takes into account where the best evidence exists regarding the best interest of the children, focusing on two main considerations: the welfare of the child and the fair and proper administration of justice. ${ }^{92}$ 


\section{OBTAINING AN ANTI-SUIT INJUNCTION}

A spouse may bring an application for an anti-suit injunction in a divorce case to prevent a spouse from pursuing a divorce in a foreign jurisdiction by meeting the criteria set out by the Supreme Court of Canada in Amchem. ${ }^{93}$ Therefore, a Canadian divorce petitioner may attempt to bring an anti-suit injunction to prevent his/her spouse from bringing a divorce application in the covenant marriage state. However, where the spouse cannot meet the Anchem test and a foreign jurisdiction grants the parties a divorce in advance of a Canadian court decision, the Canadian divorce petition will be struck because the partics are already divorced. In Harris v. Murray, ${ }^{44}$ the Court applied the Amchem anti-suit injunction test to divorce proceedings. In that case, the wife sued for a divorce in Alberta and moved for an anti-suit injunction to prevent her husband from pursuing his divorce action in Indonesia, where the couple had separated. While the Court found that the wife did not meet the Amchem test in order to obtain an anti-suit injunction, the Court held that she could proceed with her property division and support claim even where a divorce is granted in the foreign jurisdiction."s

\section{OTILER CONSIDERATIONS}

The Court in Nicholas went on to further set out three considerations that indicate the appropriateness of a forum. First, the Court held that a failure to consider citizenship does not undermine a determination that a foreign jurisdiction is the more appropriate forum for litigating divorce proceedings. ${ }^{96}$ Second, the Court stated that the surrounding circumstances and amount of time the parties have each spent in the jurisdictions and ties to each jurisdiction contribute to determining which jurisdiction has the closest connection to the underlying dispute in a divorce application. ${ }^{97}$ Third, the Court applied the statements of Arbour J.A. (as she then was) in Frymer - a case involving the principle of form $\mathrm{mon}$ conveniens in a commercial setting - to divorce proceedings, holding that "the question of burden of proof will rarely matter. The choice of the appropriate forum will generally resolve itself on the basis of the relative strength of the relevant factors, rather than on the determination of who is to bear the burden of proof.,

Where both parties wish to avoid the covenant marriage divorce restrictions, they may attempt to do so by agreeing that a Canadian court may hear their divorce application. However, this is not an available option for the couple as the Ontario Court of Appeal has recently emphasized that parties cannot confer subject matter jurisdiction on a court by agreement. In Rothgiesser $v$. Rothgiesser, ${ }^{\infty 9}$ neither spouse had been ordinarily resident in the province, but the South African couple consented to have the proceedings heard by a Canadian court. However, the Ontario Court of Appeal determined that the court could not

Sipro note 73.

(1995), 28 Alta. I..R. (3d) 377 (Q.B.).

thid. at para. 29.

Nicholas, stupra note 81 at para. 19.

lbid. al para. 20.

Frymerv: Breltschneider (1994), 19 O.R. (3d) 60 at 81 (C.A.) [Fngmer]. See also Nicholas, ibid. at para. 21.

(2000), 46 O.R. (3d) 577 (C.A.). 
adjudicate the divorce proceeding even though both spouses consented because parties by their agreement cannot confer jurisdiction on the coun.

Overall, the factors outlined in these cases must be considered together to determine whether the foreign jurisdiction represents the more appropriate forum. As Laforest $\mathrm{J}$. held in Hum v. T\&N PLC, "the assumption of and discretion not to exercise jurisdiction must ultimately be guided by the requirements of order and fairness, not a mechanical counting of contacts or connections [to the jurisdiction]."

\section{Stay of Procleleings}

Generally, where a forum outside of Canada is more convenient and suitable or appropriate for the ends of justice, the court has an inherent jurisdiction, preserved by statute, to stay a local action. ${ }^{101}$ In order to obtain a stay, the defendant spouse must request and persuade the court that the case should be tried elsewhere because there is a clearly more appropriate forum. ${ }^{102}$

In the case where a foreign court has assumed jurisdiction over the issue, a Canadian court will consider this as a factor against granting a stay of proceedings. Justice Sopinka explained the importance of this factor in Amchem: "When there is a genuine disagreement between the courts of our country and another, the courts of this country should not arrogate to themselves the decision for both jurisdictions." 103

The Court in Kornberg ${ }^{10+}$ analyzed whether the statements of Amchem, a case that involved commercial and civil actions, applied equally to a court's authority to grant a stay in divorce proceedings. Justice Philip concluded that divorce proceedings do not give rise to special considerations requiring an alteration of the general principles because no public policy reasons favour a departure from them. ${ }^{105}$ First, Philip J.A. concluded that it does not warrant special consideration because a divorce proceeding does not become prima facie unjust or vexatious when a spouse commences two actions, one in Canada and one in a foreign jurisdiction. ${ }^{106}$ Second, he found that the court's reluctance to interfere where the plaintiff in one jurisdiction is the defendant in another applies equally to divorce proceedings. ${ }^{107}$ Applying this reasoning to the covenant marriage context, a spouse who brings an action in the covenant marriage state in response to a spouse who commences the petition for divore in Canada simultaneously becomes the plaintiff in the covenant marriage state and the defendant seeking a stay of proceedings in a Canadian court.

[1993] 4 S.C.R. 289 at 326.

J.-G. Castel. Ciumediun Conflict of Lanws, 4th ed. (Markham. Ont.: Butterworths, 1997) at 244.

Amchem, supra note 73 al 912 . See also Spiliata, supra note 75.

Amchem, ibid. at 932.

Supra note 61.

lbid. at 189.

lbid.

ibid. 


\section{ASSUMing JURISDiction AND APPLYiNG THE: COVENANT MarRiage STATE LaW}

\section{The CURRENT DIVORCE ACT: AlLOWING FOR THE POSSIBILITY of Choice of Law in DivorCe Proclilidings}

As an alternative to declining to exercise jurisdiction or ordering a stay of proceedings, Canadian courts have the option of assuming jurisdiction over the divorce proceedings and applying the law of the matrimonial state. Since the Divorce $A c t^{10 x}$ does not provide direction for a court's choice of law, common law rules of conflict of laws apply. Since divorce goes to the status of spouses, the applicant spouse's personal law governs, the law of his/her domicile, lex domicilii. As the Divorce Acr only requires that a person is "ordinarily resident" in order to bring a divorce petition, a person's lex domicilii may not necessarily be Canadian law where a spouse continues his/her domicile elsewhere. ${ }^{109}$ This represents a significant change from the previous Divorce $A c t, 1968$, ." where the lex for $i$ was automatically applied because an applicant was required by the legislation to be domiciled in Canada in order to bring the divorce petition. As a result of this change from the domicile requirement to the ordinarily resident requirement, Professor Castel has suggested that "it is possible that the substantive provisions of the Divorce Act will not be applicable in a proceeding before a Canada court." "However, as this position has not been argued in court to date, it remains to be seen whether a court will accept this as a possible interpretation of the Divorce Act.

\section{A CONTRACTUAL COMPARISON: ApPLyING THE COVENANT MarRIAGE. State LAW ON THE GROUNDS TIIAT THF COVENANT MARRIAGE CONTRACT CONTAINS AN EXPRI:SS Ciroice of Law Clause}

$\Lambda$ court may ground its decision to apply the covenant marriage state law by applying conflicts of law principles similar to those applied to contracts, upon finding that a covenant marriage is comparable in many respects to a commercial contract. An interpretation of the Declaration of Intent as an express choice of law clause may form the basis for such an application. ${ }^{12}$ Generally, choice-of-law issues that arise in contracts are resolved by reference to a single law, the proper law of the contract. Where the contract contains an express choice of law clause, the test set out by the Privy Council in Vita Food Products Inc. v. Unus Shipping Co. ${ }^{113}$ continues as the current authority. In that case, Lord Wright held that a court will give effect to an express choice of law clause as long as that choice is bonafide and legal and there is no reason to avoid the choice on public policy grounds. This premise is founded on the fact that courts strive to uphold party autonomy, give effect to the parties' intentions, and maintain the fundamental principle of freedom of contract. ${ }^{14}$ Applying the

its See also Nike Infomatic Systems I.rd. v. Avac Sivtems Lre, (1979), 16 B.C.L.R. 139 (S.C.). In that casc. l.ocke J. applied the Vira Foods express choice of law principle reiterating the court's cageness to give effect to the parties" choice of law due to the principles of party autonomy and freedom of contract. 
Vita Foods test to covenant marriages, it appears likely that a court would apply the covenant marriage state law if it first found that the Declaration of Intent represented an express choice of law clause. First of all, the choice of law represented by the Declaration of Intent is bona fide in the sense that the parties did not choose the covenant marriage state law in order to evade the mandatory provisions of the system of law that is most closely and really connected with the transaction. especially considering that the covenant marriage state likely has the closest and most real connection to the transaction. Second, the choice of law is legal in the place of contracting. Finally, there do not appear to be any public policy grounds to justify avoiding the choice of the parties to apply the covenant marriage state law to their marriage, especially in light of the fact that the Supreme Court of Canada has recently confirmed that public policy grounds remain narrow. In Beals $v . S a l d a m h a,{ }^{115}$ the Supreme Court of Canada maintained the restrictive view of public policy set out by the Ontario Court of Appeal in Boardwalk Regency Corp. v. Maalouf..$^{116}$ which suggested that in order to find a violation of public policy, it must violate an essential morality that runs through the fabric of society to the extent that it is not consonant with our system of justice and general moral outlook. Applying this to the choice of law clause of a covenant marriage, it appears unlikely that giving effect to the choice that the parties made themselves to add restrictions governing their own divorce would amount to a situation that courts find contrary to essential justice that commands almost universal recognition or a principle of morality that violates deeply held Canadian public policy.

\section{OTHER CONSIDERATIONS}

Applied to a potential covenant marriage situation, a strong argument exists for a Canadian court to assume jurisdiction and apply the covenant marriage state law. As mentioned above in Part III, compelling reasons exist for affecting the restrictive grounds intended by both spouses and the covenant marriage state legislature. This option provides a Canadian court with the opportunity to validly enforee the provisions of covenant marriage in accordance with common law conflict of laws principles and the Divore' Act. Further, this represents an especially compelling option where one spouse remains domiciled in a covenant marriage state and the other spouse brings an action in Canada as an ordinary resident of a province for one year but remains domiciled in the covenant marriage state. ${ }^{17}$

\section{Conciusion}

The future success of the American statutory creation of covenant marriage, still in its early stages, faces significant challenges in light of the current application of conflict of laws principles to divorce petitions in both the United States and Canada. While the creation of this new marital regime demonstrates both the legislature's intent to introduce an additional option to marriage for its citizens, a public policy choice to promote the strengthening of

\footnotetext{
11. $2003 \mathrm{SCC} 72.12003]$ 3 S.C.R. 416.

116 (1992),6 O.R.(3d) 737 (C.A.).

1. While these compelling reasons exist for affecting the restrictive grounds of divorce under covenant marriage legislation, covenant marriages may be differentiated from olher jurisdictions that have restrictive divorec laws on the basis that the covenant marriage couples have made a conscious choice to enter into a form of marriage with restrictive grounds where the option of more liberal divores grounds existed.
} 
marriage, as well as allowing a couple to express their intention to assume obligations above and beyond a standard marriage, the current application of conflict of laws threatens the extent to which these intentions can be fulfilled. In the United States, the prevailing jurisprudence and conflicts rules indicate that sister states will apply their own state law to divorce applications. Therefore, the restrictive grounds for divorce, one of the defining features of covenant marriages, may be circumvented by spouses moving across borders. A number of alternatives to the current American treatment of divorce applications exist that would give effect to the intent of covenant marriage legislation including: (1) allowing a sister state to assume jurisdiction over the divorce petition but apply the covenant marriage legislation; (2) having a sister state apply commercial contract principles to the legislated choice of law clause contained in the covenant marriage contract, and also the corresponding commercial contract conflicts principles; and/or (3) introducing federal legislation to enforce fundamental features of covenant marriage legislation.

Meanwhile, the Canadian conflict of laws treatment applied to divorce petitions offers a greater possibility that a covenant marriage's elements will be upheld as it limits the ability for a spouse to circumvent the restrictive grounds by becoming ordinarily resident in Canada. Although the ordinarily resident requirement is arguably easier to establish than the American domicile requirement, the common law factors that determine whether Canada represents the form conveniens, and therefore whether a Canadian court will accept jurisdiction over the divorce petition, favour recognizing a covenant marriage state's jurisdiction in dissolving a covenant marriage. In light of the lack of personal or juridical disadvantage in returning the divorce proceedings to a covenant marriage state, whether a Canadian court decides to grant a stay of proceedings or return the divorce petition to the covenant marriage state depends largely on the facts of the case. In the case where the bulk of marital assets and/or children remain in a covenant marriage state, a court will likely decide to decline to exercise jurisdiction as courts strongly favour trying custody and support issues together with divorce proceedings.

Finally, in light of the fact that the Divorce $\mathrm{ACl}^{11 \mathrm{~s}}$ only requires a person to be "ordinarily resident" in Canada for a year to bring a divorce petition, the possibility remains open for a Canadian court to assume jurisdiction over the divorce application and apply the law of the covenant marriage state as their choice of law. As divorce affects a person's status, the petitioner's personal law applies. Therefore, since a petitioner's personal law is his/her lex domicilii, a court may validly apply the law of the covenant marriage state if the petitioner continues to remain a domiciliary in that state. Absent any additional facts regarding a covenant marriage couple, this option represents the most effective method that respects the choices that both parties made in entering a covenant marriage and a covenant marriage state's legislative intent while simultaneously advancing the application of the appropriate conflict of laws principles and Divorce Acl provisions. 